\title{
ЦВЕТООБОЗНАЧЕНИЯ В ЯЗЫКЕ ПОЭЗИИ АВТОРОВ ХХ ВЕКА
}

\section{COLOR DESIGNATIONS IN THE LANGUAGE OF THE POETRY OF THE AUTHORS OF THE XX CENTURY}

\section{S. Petrova}

Summary: The article examines the features of the functioning of colorative vocabulary in literary texts of poets of the twentieth century. The semantics and functional orientation of color designations are described, in the role of which the names of the element EARTH are actively used. The features of the figurative implementation of colorative vocabulary in the poetic texts of the authors of the period under study are investigated. A comparative analysis of the lexical specification of color designations in the poetry of A. Blok, V. Mayakovsky, S. Yesenin, B. Akhmadulina, A. Voznesensky, E. Evtushenko is carried out.

Keywords: color designation, metaphor, metaphorical epithet, artistic image, semantics, vocabulary.

\author{
Петрова Светлана Владимировна \\ к.филол.н., дочент, Белгородский государственный \\ национальный исследовательский университет \\ petrova@bsu.edu.ru
}

Аннотация: В статье рассматриваются особенности функционирования колоративной лексики в художественных текстах поэтов XX века. Описывается семантика и функциональная направленность цветообозначений, в роли которых активно используются наименования стихии ЗЕМЛЯ. Исследуются особенности образной реализации колоративной лексики в поэтических текстах авторов исследуемого периода. Проводится сопоставительный анализ лексической спецификации цветообозначений в поэзии А. Блока, В. Маяковского, С. Есенина, Б. Ахмадулиной, А. Вознесенского, Е. Евтушенко.

Ключевые слова: цветообозначение, метафора, метафорический эпитет, художественный образ, семантика, лексика.
$\mathrm{O}$ бращение к исследованию цветообозначений с точки зрения функционирования их в поэтических текстах авторов XX века направлено на анализ семантики лексических единиц, особенностей сочетаемости колоративов с целью выявления их образного потенциала. Именно в ткани произведения отдельные лексемы и фразы, взаимодействуя, приобретают разнообразные смысловые оттенки. По справедливому замечанию В.В. Виноградова, «смысл слова в художественном произведении никогда не ограничен его прямым номинативно-предметным значением. Буквальное значение слова здесь обрастает новыми смыслами... В контексте всего произведения слова и выражения, находясь в теснейшем взаимодействии, приобретают разнообразные дополнительные смысловые оттенки, воспринимаются в сложной и глубокой перспективе целого» [1, с. 230].

Цветообозначения не один раз привлекали внимание исследователей-филологов. Ученые по разным основаниям классифицируют слова-цветообозначения, выделяют неодинаковое количество основных колоративов. Для русского языка, согласно теории Б. Берлина и П. Кея (Berlin B., Kay P., 1991), основными цветообозначениями являются 12 прилагательных: черный, белый, красный, зеленый, синий, желтый, коричневый, голубой, фиолетовый, оранжевый, серый и розовый. Наиболее частотными среди носителей языка являются прилагательные: зеленый, голубой, красный, желтый, синий, коричневый, белый, черный, серый. Для более точного определения оттенка всегда необходим достаточный контекст, то есть ближайшее окружение слова, особенно это касается функционирования слов-цветообозначений в художественном тексте, поскольку именно там может рождаться новый смысл, который существует только в языковой картине конкретного автора.

В рамках данной работы мы обратились к корпусу лексических единиц, которые по своей семантике связаны со стихией ЗЕМЛЯ. Как показал анализ лексического массива текста, именно данные номинации активно функционируют в качестве цветообозначений в языке поэзии авторов XX века (А. Блока, В. Маяковского, С. Есенина, Б. Ахмадулиной, А. Вознесенского, Е. Евтушенко). Обращение к специфике колоративов в художественных текстах поэтов, ставших знаковыми фигурами современности, а также сопоставление со цветообозначениями в поэзии начала XX (А. Блока, В. Маяковского, С. Есенина) является небезынтересным, так как это позволит выявить некоторые закономерности в образном употреблении колоративов, а также отметить особенности индивидуально-авторского восприятия цветовой картины мира.

В поэтическом языке данных авторов происходит качественное преобразование содержания земных лексем, появление у них новых смысловых оттенков. Номинации стихии ЗЕМЛЯ, функционируя в текстах указанных авторов в качестве колоративов, с одной стороны сохраняют свое понятийное значение, с другой - обретают образное наполнение, которое характеризуется богатством ассоциаций.

Наиболее частотными в текстах художников слова 
являются номинации, которые входят в тематические группы «Наименования горных пород, камней и драгоценных металлов» (золото, серебро, жемчуг, изумруд, медь, янтарь, мрамор, агат, рубин, бронза, бирюза, олово, уголь, яхонт), «Наименования растений и их частей» (фиалка, рябина, маслины, чернослив, мандарин, персик, томат, вишня, черника, васильки, настурция, апельсин, сирень, кувшинка, незабудка, черемуха, фисташки, абрикос, мак, маргаритка, роза, смородина, орех).

Цветовая картина мира поэтов формируется на основе национальной, но преобразуется, дополняется новыми коннотациями, которые обусловлены особенностями индивидуально-авторского мировосприятия. Образные наименования появляются, когда слова-цветообозначения вплетаются в структуру тропа (чаще метафоры и эпитета). Когда поэт воссоздает цветовую картину мира, он основывается не только на объективном восприятии цвета, но и на экспрессивном ощущении, отмечая в языке возникшие смысловые ассоциации. Эти новые коннотации совмещают в себе понятийную и чувственную сферу познания, способствуют созданию художественных образов, приращению новых компонентов значения.

В поэтических текстах А. Блока, В. Маяковского, С. Есенина, Б. Ахмадулиной, А. Вознесенского, Е. Евтушенко колоративные наименования представлены группами красного, желтого, серого, черного, синего, голубого, зеленого, белого цветов, а также их оттенками.

Наиболее употребительными в художественных текстах всех авторов являются колоративы «желтый» и «серый», наиболее частотны они в языке поэзии С. Есенина, А. Блока. Цветообозначения из текстов С. Есенина, А. Блока, В. Маяковского приводятся из «Словаря образных средств Александра Блока, Сергея Есенина и Владимира Маяковского» Н.А. Тураниной. Так, приведем некоторые примеры:

у А. Блока: золото ресниц; золото кудрей; осеннее злато; золотистые лица купальщиц; золотые пряди; золотые опилки; золотой колосок; в золотую осень разлук; золотого заката; в серебре росы; в серебре метелей; серебром моих вьюг, серебром волны (Туранина, 2009);

у С. Есенина: лижут сумерки золото солнца; осеннее золото лип; посмотреть на золото телесное; в золото полей; золото овса; это золото осеннее; золото холодное луны; в лунном золоте; в волосах есть золото и медь; руки милой - пара лебедей - в золоте волос моих ныряют; лижут сумерки золото солниа; как осеннее золото лип; в золото полей; золото овса; увяданья золотом охваченный; золото холодное луны; на ветке облака, как слива, златится спелая звезда; реки златых долин; над рощею ощетинится златым щенком луна; на златых моих ресницах; на нивы златые; златое солнышко, как пуп, глядит в Каспийский рот; пополам нашу землю-матерь разломлю, как златой калач; солнца луч золотой; в блеске золотом; в лучах золотых (Туранина, 2009);

у В. Маяковского: Снег серебрит телеграфную сеть; серебряный Дон; в ночи Млечный путь серебряной Окою (Туранина, 2009).

В текстовом пространстве Б. Ахмадулиной, А. Вознесенского, Е. Евтушенко лексемы серебро, золото также достаточны частотны в качестве цветообозначений.

у Б. Ахмадулиной: злато дыни; За ели западал сплав ржавчины и злата (о солнце). / Оранжевый? Жаркой?... (Ахмад, 1, 210, 276); А как стали вставать, с неохотой глаза открывать, / вдоль метели пронесся трамвай, изнутри золотистый (Ахмад., 2, 257). Пусть я сгину, / подрагивая в чистом серебре русалочьих мурашек, / жгущих спину! (Ахмад., 1, 170); вод холодных серебро; Кровь звезд и бездн под кожей серебрится (Ахмад., 2, 135, 241);

у Е. Евтушенко: серебряная россыпь голубей; рубины самолета (Евтуш., 3, 209, 244); В перманенте рыжем серебряно / проступали седые пряди (Евтуш., 2, 75); золотая струя горчицы; золотые нити спагетти; серебристая полынь (Евтуш., 2, 238; 3, 340, 470); золотой хохолок (о ребенке) (Евтуш., 3, 408);

у А. Вознесенского: Потом облака золотели от зноя. / И сонное солние в Элладу ушло (Вознес., 1, 372); серебряны глаза (Вознес., 1, 318).

В поэтическом дискурсе указанных авторов колоративы «желтый», «серый» используются как средство создания лингвистического портрета человека, а также для описания природных явлений и объектов окружающего мира.

Колоративы «белый», «зеленый», «голубой», «фиолетовый», «черный» представлены в поэзии Б. Ахмадулиной, Е. Евтушенко А. Вознесенского такими репрезентантами стихии ЗЕМЛЯ как, жемчуг, маслины, фиалки, незабудки, фисташки, василек, брусника, изумруд, рубин, например:

у Е. Евтушенко: С колыбели / голубели / у Ивана-дурака / под бровями два хитрющих, / два живучих василька (о глазах); И каждым утром / ранней ранью / нас пробуждал нетерпеливо, / качая синий мед желанья.../ Желанье тлело сквозь ресничины / и на груди твоей вздымало / две сан-луисские брусничины (о сосках на женской груди) (Евтуш., 3, 370, 417); рубины самолета (Евтуш., 3, 209, 244); Глядела с любопытством, / а не вчуже, / и вовсе не старушечье - / девчушье / синело из-под треснувших очков / слукавым простодушьем васильков (Евтуш., 3, 281); изумрудная тина; незабудочные явтушенковские глаза (Евтуш, 2, 524; 3, 337);

У А. Вознесенского: бирюза кокошников; На черном пластике / изумрудно / сжимались празднично / два чутких чуда (о лягушках)... (Вознес., 1, 81; 3, 109); жемчужные парики; глаза фисташковые; (Вознес., $1,288 ; 2,303)$. 
у Б. Ахмадулиной: Коль жаждешь - пей до дна черничный сок зрачка (Ахмад., 3, 37); маслины ивета (Ахмад., 2, 262).

В поэтических текстах Е. Етушенко, Б. Ахмадулиной, А. Вознесенского колоративы «желтый», «серый», «коричневый», «черный» выражены сложным прилагательным или прилагательным-неологизмом, которые в свою очередь являются индивидуально-авторскими эпитетами. Например: в стрижечке светло-ореховой; жемчужно-витиеватая береза; сиянье моря северно-янтарное; ящики с шампанским серебряноголовые; глаз твой агаmист (Вознес., 1, 232, 243, 279; 2, 81; 3, 91); аксамитовожемчужные росы; рудо-желтая луна (Евтуш., 3, 66, 413); воды серебряно-черненые (Ахмад., 2, 286).

Яркие примеры конвергенции тропов с использованием цветообозначений представлены в поэтическом языке С. Есенина: Загорятся, как черна смородина, угли - очи в подковах бровей; Словно яблонный цвет седина у отца пролилась в бороде (Туранина, 2009).

Совмещение тропов в одном контексте с использованием колоративов также характерно и для поэзии Б. Ахмадулиной, А. Вознесенского, Е. Евтушенко, например: ... словно три изумрудные взрыва, / эти лиственницы стоят; (Евтуш., 2, 141); уток нитка жемчужная; Одуряя и журя, / полыхает мандарином / рыжей челки кожура; (Вознес., 1, 81); гений глаза изумрудный; янтарное озеро паркета (Ахмад., 1, 273; 3, 17).

Как показал анализ колоративов, встретившихся в поэтическом дискурсе исследуемых авторов, цветообозначения чаще всего выражены согласованным определением, существительным со значением признака, глагольной формой или наречной структурой.

Репрезентанты стихии ЗЕМЛЯ в поэзии А. Блока, В. Маяковского, С. Есенина, Б. Ахмадулиной, А. Вознесенского, Е. Евтушенко активно используются качестве цветообозначений, вовлекаются при этом в метафорический процесс, что позволяет авторам создавать яркие и необычные поэтические образы. В ряде случаев колоративная лексика в текстах авторов представляет собой пример традиционного образоупотребления цветообозначений, что позволяет говорить о продолжении традиций русских поэтов в создании цветовой картины мира. Однако некоторые образные употребления цветообозначений отражают индивидуально-авторское восприятие реалий окружающей действительности. Колоративы активно используются авторами в переносном значении в составе метафоры и эпитета, сравнения для создания различных по семантике художественных образов. В творчестве поэтов конца XX - начала XXI вB. встречаются цветообозначения, не актуализировавшиеся ранее.

\section{ЛИТЕРАТУРА}

1. Ахмадулина, Б.А. Сочинения: В 3 т. / Б.А. Ахмадулина. - М.: ПАН • Корона-Принт, 1997.

2. Ахмадулина, Б.А. Стихотворения. Эссе / Б.А. Ахмадулина. - М.: АСТ, Астрель, Олимп, 2000. - 507 с.

3. Ахмадулина, Б.А. Блаженство бытия: Стихотворения / Б.А. Ахмадулина. - М.: ЭКСМ0-Пресс, 2001. - 412 с.

4. Вознесенский, А.А. Собрание сочинений: В 3 т. / А.А. Вознесенский. - М.: Художественная литература, 1983 -1984.

5. Вознесенский, А.А. Собрание сочинений: в 5 т. Т. 2. / А.А. Вознесенский. - М.: Вагриус, 2002. - 416 с.

6. Вознесенский, А.А. Собрание сочинений: в 5 т. Т. 4. / А.А. Вознесенский. - М.: Вагриус, 2002. - 544 с.

7. Вознесенский, А.А. Собрание сочинений: в 5 т. Т. 5. / А.А. Вознесенский. - М.: Вагриус, 2003. - 416 с.

8. Евтушенко, Е. А. Стихотворения и поэмы: в 3 т. / Е. А. Евтушенко. - М.: Советская Россия, 1987.

9. Евтушенко, Е.А. Собрание сочинений: в 8 т. / Е.А. Евтушенко. - М.: Изд-во АСТ, 2003.

10. Виноградов В.В. Наука о языке художественной литературы. - М., 1958. - 214 с.

11. Туранина Н.А. Словарь образных средств Александра Блока, Сергея Есенина и Владимира Маяковского. - Москва-Белгород, 2009. - 176.

12. Харченко В.К. Словарь цвета: концепция, новые материалы, полная электронная версия. - Москва: Лит. ин-т им. А.М. Горького, 2013. - 207 с.

13. Berlin B., Kay P. Basic color terms: their universality and evolution. Berkeley: University of California Press, 1991. P. 2.

(c) Петрова Светлана Владимировна (petrova@bsu.edu.ru). 